\title{
DELOVANJE SLOVENSKE VOJSKE V ČASU EPIDEMIJE COVIDA-19
}

Povzetek V prispevku je predstavljen pojav epidemije covida-19 v Republiki Sloveniji, s poudarkom na delovanju Slovenske vojske. Opisujemo odziv Slovenske vojske na epidemijo in postopke ter procese, ki jih je izvajala na svojih nalogah tako doma kot v mednarodnih operacijah in na misijah v tujini, ter omogočila dodatno podporo državi in državljanom pri spoprijemanju z novim virusom. Poudarek je na postopkih in procesih, vodenih v Vojaški zdravstveni enoti, za spremljanje epidemioloških razmer. Delovanje Slovenske vojske, ki se navezuje na delovanje njihovih zdravstvenih enot med epidemijo covida-19, primerjamo z nekaterimi drugimi oboroženimi silami.

Ključne besede

\section{Covid-19, epidemija, virus, Slovenska vojska, Vojaška zdravstvena enota.}

Abstract The article presents the phenomenon of the COVID-19 epidemic in the Republic of Slovenia with focus on the activities of the Slovenian Armed Forces. It describes the response of the Slovenian Armed Forces to the epidemic, and the procedures and processes applied as part of its missions at home and in international operations and missions abroad. These activities provided additional support to the state and its citizens in dealing with the new virus. The emphasis is put on the procedures and processes of the Military Medical Unit aimed at monitoring the epidemiological situation. Additionally, the epidemic-related activities of the Slovenian Armed Forces and its medical units are compared to the activities of several other armed forces. 
Uvod Leto 2020 je zaznamoval nepričakovan izbruh novega virusa, ki je globalno spremenil svet. Svetovna zdravstvena organizacija je 28. februarja 2020 razglasila pandemijo. Javni zdravstveni sistemi držav so se znašli pred hudo preizkušnjo. Strokovnjaki različnih ved so se začeli povezovati in preučevati dogajanje, iskati vzroke in rešitve ter pripravljati strokovna navodila glede preprečevanja širjenja nalezljive bolezni covid-19. Svet se je znašel pred veliko preizkušnjo.

Po razglasitvi pandemije so strokovnjaki pridobili že prva spoznanja in dejstva o povzročitelju nalezljive bolezni covid-19. Poleg osnovnega dejstva, da se virus širi kapljično in da se z veliko afiniteto veže na človeške epitelijske celice predvsem v pljučih, je bilo vedno več novih dokazanih simptomov okužbe ter nastalih poškodb notranjih organov kot posledica okužbe $\mathrm{z}$ novim virusom. ${ }^{1}$ Zelo pomembna je bila ugotovitev vrednosti bazičnega reproduktivnega števila $\left(\mathrm{R}_{0}\right)$, »»ki predstavlja povprečno število sekundarnih primerov, ki jih bo povzročila okužena oseba $\mathrm{V}$ za okužbo dovzetni populaciji. Povprečno število novih primerov v populaciji je odvisno od števila tesnih stikov (k), verjetnosti, da bo prišlo do prenosa okužbe ob stiku (v), trajanja kužnosti (T) in deleža oseb, ki so za nalezljivo bolezen dovzetne (s). V primeru, da so vse osebe sprejemljive za določeno nalezljivo bolezen, bo število sekundarnih primerov odvisno od: $\mathrm{R}_{0}=\operatorname{kxvxTxs} \ll$ (Frelih, 2012, str. 10). Če je vrednost $R_{0}>1$, se bo povzročitelj bolezni učinkovito širil po populaciji. $V$ takem primeru sta potrebna takojšen nadzor nad boleznijo in uvedba preventivnih ukrepov.

V Sloveniji je bila 12. marca 2020 prvič razglašena epidemija covida-19. Aktiviran je bil državni načrt. Najpomembnejši organ pri izdajanju priporočil in strokovnih usmeritev je bil Nacionalni inštitut za javno zdravje (NIJZ), ki je javnost pozval k obveznemu nošenju zaščitnih mask v prostorih, ohranjanju medosebne razdalje vsaj 1,5 metra, umivanju in razkuževanju rok, izogibanju tesnim stikom ter razkuževanju površin. $^{2}$

Odziv je bil nujen tako na državni ravni kot tudi znotraj SV. SV je v 72 urah postavila premično bolnišnico Role 2 z zmogljivostjo do 140 bolniških postelj, namenjenih za oskrbo obolelih državljank in državljanov. Generalštab SV se je krizno organiziral, prav tako je Poveljstvo sil SV kot nosilec načrtovanja in vodenja dejavnosti svoje poslanstvo usmerilo v podporo preprečevanja širjenja covida-19 na vseh ravneh vodenja in poveljevanja v SV (PSSV, 2020, str. 1). SV je pomagala državljanom Slovenije pri vrnitvi v domovino ter evakuaciji obolelih pripadnikov SV z mednarodnih misij in iz operacij. Z aktiviranjem Državnega načrta zaščite in reševanja ob pojavu epidemije nalezljive bolezni pri ljudeh je SV pomagala predvsem z materialnimi sredstvi in logistično podporo ter kadrovskimi zmogljivostmi.

\footnotetext{
Coronavirus Disease 2019, Questions and Answers. https://www.cdc.gov/coronavirus/2019-ncov/

Priporočila za preprečevanje okužbe z virusom, https://www.nijz.si/sl/priporocila-za-preprecevanje-okuzbe-zvirusom-sars-cov-2
} 
V prvem valu epidemije smo v SV prilagodili in uvedli preventivne ukrepe glede usmeritev in navodil NIJZ ter vladnih ukrepov. V drugem valu epidemije smo poleg že sprejetih ukrepov sprejeli in uvedli še dodatne in selektivne ukrepe, vendar je bilo med pripadniki SV zaznati povečano število okužb s covidom-19 v primerjavi s prvim valom epidemije. Vojaška zdravstvena enota (VZE) je imela pomembno vlogo, saj je s spremljanjem epidemioloških razmer v državi in SV, z izdajanjem strokovnih navodil za preprečevanje širjenja virusa pravočasno obveščala poveljnika sil ter pripomogla k njegovim odločitvam. V VZE se je vzpostavil sistem sledenja visoko rizičnih stikov, preventivnih testiranj ter pravočasno izločanje okuženih iz kolektiva. Skladno s postopkovnikom za izvedbo PCR (Polymerase Chain Reaction - verižna reakcija s polimerazo) in hitrih antigenskih testov so te opravljali pred odhodom pripadnikov na varovanje državne meje, pred odhodom na neodložljiva skupinska usposabljanja ter pred odhodi v mirovne operacije in na misije (MOM). Omeniti je treba še cepljenje proti covidu-19 kot enega najučinkovitejših ukrepov pri preprečevanju širjenja nalezljive bolezni.

V članku bi radi ugotovili, katera spoznanja in dobre prakse odziva na epidemijo nalezljivih bolezni smo sprejeli in se jih naučili in katere so uporabne v morebitnih prihodnjih kriznih razmerah.

\section{ODZIV NEKATERIH TUJIH OBOROŽENIH SIL NA COVID-19}

Odziv na covid-19 v tujih oboroženih silah je bil podoben odzivu SV. Navajamo nekaj primerov odziva »velikih« oboroženih sil v času epidemije.

Pasquier pravi, da je francoski predsednik Emmanuel Macron nagovoril ljudstvo z besedami »Mi smo v vojni.« Le v nekaj tednih je francoska vojaška zdravstvena služba (FMMS - French Military Medical Service) vzpostavila hitro sestavljive zdravstvene zmogljivosti za podporo nacionalnim zdravstvenim strukturam in drugim državnim organom. Tako so vzpostavili poljsko bolnišnico z intenzivno enoto za bolnike s covidom-19 ter zračno in pomorsko evakuacijo obolelih državljanov in pripadnikov francoske vojske. Strokovnjaki Vojaškega centra za epidemiologijo (FMCE - French Military Centre for Epidemiology) so v sodelovanju z Nacionalnim inštitutom za zdravje (PH - Public Health) pridobivali vse potrebne informacije o covidu-19, izdajali usmeritve in navodila ter jih posredovali odločevalcem (2020, str.1).

Po navedbah Pasquierja so francoske oborožene sile v nekaj tednih vzpostavile primarni nivo zdravstvene oskrbe bolnikov, uporabo telemedicine, poljske bolnišnice z intenzivno enoto za 47 bolnikov s covidom-19 in drugimi respiratornimi obolenji ter medicinsko evakuacijo (po tleh, zraku in morju). V osmih vojaških bolnišnicah so v sodelovanju s civilnimi zdravstvenimi strukturami obravnavali več kot 9000 bolnikov. Vojaška logistika je zagotavljala medicinsko opremo vsem vojaškim zdravstvenim ustanovam $\mathrm{v}$ Franciji in tujini. Vojaški inštitut za biomedicinske 
raziskave je vsak dan zagotavljal strokovna priporočila in navodila ter usmeritve glede biološke varnosti (po Pasquier, 2020, str. 1).

Sodelovanje med francoskim letalstvom in FMMS je razvilo sistem zračne medicinske evakuacije, pri čemer so uporabili vojaško letalo Airbus A330, opremljen z modulom enote za intenzivno nego do šest bolnikov z možnostjo opravljanja daljših razdalj, kar prikazuje slika 1 (str. 108). Opravili so 36 zračnih medicinskih evakuacij, šest letov je trajalo od 52 minut do 77 minut na višini od $700 \mathrm{~km}$ do $108 \mathrm{~km}$ (Pasquier, 2020, str. 2).

Direktorat zdravstvene zaščite kanadskih oboroženih sil (DFHP - Directorate of Force Health Protection) navaja, da je bila vloga zdravstvene zaščite obrambnih sil od pojava covida-19 močno vpeta v spremljanje izbruha bolezni, zdravstvenega nadzora, razvoja politike ter sodelovanja $\mathrm{z}$ mednarodnimi agencijami za javno zdravje. Delovanje kanadskih oboroženih sil se v mednarodnih operacijah ni ustavilo, temveč je DFHP za zaščito lastnih sil nemudoma organiziral usposabljanja iz osnovnih zaščitnih ukrepov ter zagotavljal osebno varovalno opremo. DFHP je v sodelovanju z nacionalnim zdravstvenim sistemom razvil sistem sledenja tesnih stikov okuženih ali suma na okužbo z novim koronavirusom (Edge, 2020, str. 279).

Primer odziva bolgarskih oboroženih sil na koronavirusno krizo po besedah Tagareva temelji na tem, da imajo oborožene sile posebne zmogljivosti, ki jih civilne zdravstvene organizacije nimajo, zlasti, kadar so potrebni ukrepi nujni v okolju z visokim tveganjem. Trinajstega marca 2020 je bolgarska vlada razglasila izredne razmere in uvedla številne omejitvene in preventive ukrepe proti širjenju bolezni covid-19 (2020, str. 61). Kot navaja Tagarev, se je organiziral Nacionalni operativni štab (NOHQ - National Operational Head Quarter), ki ga je vodil generalmajor in vojaški kirurg, direktor vojaške medicinske akademije, v sodelovanju z dvema medicinskima strokovnjakoma iz Nacionalnega centra za nalezljive bolezni ter tremi strateškimi uradniki z ministrstva za notranje zadeve. Operativni štab je takoj začel pridobivati podatke glede števila opravljenih testov, novih primerov okužbe, števila primerov na intenzivni negi ter števila smrtnih primerov (2020, str. 65). Tagarev omeni pomembno vlogo vključitve obrambnega ministrstva v nacionalni odbor za pandemijo bolezni covid-19, ki jo določa Zakon o zaščiti pred nesrečami. Poleg tega je država že imela pripravljen Državni načrt za primer pandemije gripe. »Sodelovanje vojske pri obvladovanju pandemije covida-19 in izrednih razmer v Bolgariji je prispevalo k vzpostavljanju zaupanja javnosti in družbenega spoštovanja oboroženih sil« (Tagarev, 2020, str. 65-73).

\section{ODZIV SLOVENSKE VOJSKE NA COVID-19}

Poleg bistvenih nalog SV, kot so skrb za nacionalno varnost, vzdrževanje ustrezne stopnje pripravljenosti, krepitev sodelovanja in zaupanja med SV ter vojskami zavezniških in prijateljskih držav (Kremžar, 2014, str. 107), ima SV v zadnjem času vedno večjo vlogo v kriznih razmerah. Naloge SV, ki izhajajo iz njenega poslanstva, 
so uresničevanje interesov in nacionalnovarnostnih ciljev Republike Slovenije s sodelovanjem $\mathrm{v}$ mednarodnih operacijah in na misijah, zagotavljanje dvonamenskih zmogljivosti ter sodelovanje pri nalogah zaščite, reševanja in pomoči ob naravnih in drugih nesrečah skladno z načrti, opremljenostjo in usposobljenostjo SV (Resolucija o splošnem in dolgoročnem programu razvoja in opremljanja SV do leta 2025, 2010).

\subsection{Vloga Slovenske vojske v kriznih razmerah}

Oborožene sile SV so vse pogosteje vpete v sodelovanje kriznega menedžmenta, mirovnih, humanitarnih in drugih neklasičnih vojaških operacij. Poleg tega morajo opravljati predvsem tradicionalno nalogo, to je obrambo države pred zunanjimi napadi (Pliberšek, 2012, str. 30).

Kot navaja Furlan, se v vsaki krizi ustvari situacija, ki lahko ogrozi nacionalno ali mednarodno varnost. Definicija krize, povzeta iz Vojaške doktrine, je stanje, dogodek, proces v državi in zunaj nje, ki predstavlja grožnjo temeljnim nacionalnim interesom in družbenim vrednotam. Ni je mogoče rešiti z običajnimi sredstvi in dejavnostmi podsistemov nacionalne varnosti, temveč zahteva angažiranje kriznega upravljanja. Značilna sta negotovost in razmeroma kratek čas za ukrepanje (2006, str. 10).

SV se je s kriznimi razmerami, tako naravnimi kot humanitarnimi, srečevala že v preteklosti. Pridobljene izkušnje iz ujm (poplave in žled) ter migrantske krize nam leta $2020 \mathrm{z}$ izbruhom nalezljive bolezni niso dosti pomagale. Pri epidemiji nalezljive bolezni moramo poudariti, da pri kriznem upravljanju ne gre le za reševanje krize, ampak predvsem za preventivno delovanje.

Leta 2015, v času t. i. migrantske krize, so bili pripadniki SV glede na epidemiološko sliko držav, iz katerih so prihajali ilegalni migranti, preventivno ozaveščeni o morebitnih okužbah in boleznih. V tem primeru ni šlo samo za nacionalno varnost, temveč tudi za varnost pred nalezljivimi boleznimi, predvsem strateško pomembnimi boleznimi, ki šele čez desetletja lahko zanihajo narodnostno ravnovesje. Kot navaja Brožič, smo z epidemijo ilegalne migracije postavili na stranski tir, kar se z vidika nacionalne varnosti ne sme zanemariti (2020, str. 84).

\section{Vzdrževanje stopnje pripravljenosti Slovenske vojske med epidemijo}

Poveljnik sil SV, ki vodi in poveljuje podrejenim poveljstvom in enotam, načrtuje usposabljanja poveljstev in enot SV ter zagotavlja zahtevano stopnjo pripravljenosti, je sprejel odločitev za nemoteno delovanje SV, ne glede na izvajanje vseh ukrepov, povezanih s preprečevanjem širjenja nalezljive bolezni covid-19.

Skladno z epidemiološko situacijo in po aktivaciji Državnega načrta zaščite in reševanja ob pojavu epidemije so bili zagotovljeni optimalni pogoji za uporabo vojaških zmogljivosti za izvajanje nujnih nalog ter nalog v podporo državi in njenim državljanom pri omejevanju in preprečevanju širjenja bolezni covid-19. Čeprav je bil izdan dokument o zmanjšanju prisotnosti pripadnikov SV na delovnem mestu 
in o delu od doma, so bile naloge kljub temu opravljene (MO, 2020, str. 2-4). Z zmanjšano prisotnostjo pripadnikov na delovnem mestu je bilo preprečeno širjenje okužb in zagotovljeno zdravje pripadnikov SV, hkrati pa se je vzdrževala stopnja pripravljenosti.

V drugi polovici marca 2020, ko je epidemija dosegla vrhunec, je bila okuženost med pripadniki SV zelo nizka, kar kaže tudi statistika obolelih. Iz operativnih dokumentov SV je razvidno, da so poveljstva in enote na vseh ravneh vodenja in poveljevanja bile pripravljene na nov izziv - izvedbo sklopa vaj Preskok $2020^{3}$. $\mathrm{Na}$ podlagi kontinuiranega spremljanja epidemiološke situacije smo skladno $\mathrm{z}$ navodili in usmeritvami NIJZ izdajali in ozaveščali pripadnike SV z novimi ukrepi preprečevanja širjenja covida-19 (MO, 2020, str. 1-6). Na vaji Preskok 2020, na kateri so sodelovali pripadniki stalne sestave in pogodbene rezerve, je bila zagotovljena visoka raven discipline ter samozaščite. Zdravstvena podpora je bila zagotovljena $\mathrm{z}$ lastnimi silami.

Vojaška zdravstvena enota se je v svoji strukturi strokovnega osebja (zdravnik, epidemiolog, mikrobiolog, biolog, sanitarni inženir in zdravstvenik) na podlagi strokovnih usmeritev za preprečevanje širjenja okužb, ki jih je pridobila zdravstvena stroka na ravni NIJZ, GŠSV ter PSSV, zelo uspešno organizirala in ves čas epidemije izvajala taktične naloge glede preprečevanja širjenja bolezni. Po navedbah dokumentov PSSV so se oblikovale mobilne strokovne ekipe za podporo pripadnikom SV skozi celoten niz vaj Preskok 2020, ki so zagotavljale primarno zdravstveno oskrbo, odvzem brisa ter dezinfekcijo prostorov in opreme (MO, 2020).

Pripadnike SV smo opremili z osebno zaščitno opremo, jih nenehno ozaveščali s spreminjajočim se epidemiološkim položajem in usmeritvami ter navodili za preprečevanje širjenja covida-19. Eden od izzivov je bil tudi pravočasen prevoz zaščitne opreme, namenjene preprečevanju širjenja bolezni, kar je bilo povezano s pridobivanjem diplomatskih dovoljenj za lete zunaj države (PSSV, 2020, str. 2-3). V vseh vojašnicah in vojaških objektih je bil zagotovljen prostor za izolacijo pripadnika, če je ta kazal značilne bolezenske znake. V VZE se je zdravstveno osebje usposobilo za pravilen odvzem brisov in ustanovljene so bile mobilne medicinske ekipe. V biološkem mobilnem laboratoriju so po metodi rt-PCR opravljali analize brisov za pripadnike SV. Oblikovane so bile tudi mobilne ekipe za dezinfekcijo prostorov in opreme. Po odločitvi poveljnika sil SV so na vseh vstopnih točkah v vojašnicah in vojaških objektih mobilne ekipe VZE merile telesno temperaturo vsem pripadnikom, saj je to eden od pokazateljev možnosti okužbe s covidom-19 (VZE, 2020, str. 1-2).

\footnotetext{
3 Na vaji Preskok je sodelovalo približno 2500 vojakov, vključenih je bilo 59 občin, potekala pa je 67 dni. Vajaje potekala na podlagi odločitve Vlade RS in sprejetega Načrta vaj v obrambnem sistemu in sistemu varstva pred naravnimi in drugimi nesrečami.
} 


\section{Vloga Slovenske vojske v podpori državljanom pri spoprijemanju s covidom-19}

Zaradi spremljanja globalnih epidemioloških razmer in resnosti ogrožanja zdravja ne le pripadnikov SV, temveč vseh prebivalcev, je poveljnik sil SV sprejel odločitev o postavitvi premične vojaške bolnišnice Role $2 \mathrm{v}$ vojašnici Edvarda Peperka v Ljubljani. Skupaj s pomočjo Uprave Republike Slovenije za zaščito in reševanje, ki je ponudila namestitvene zmogljivosti, smo v SV postavili premično bolnišnico Role 2, ki je zagotavljala 40 postelj za težje bolnike in 80 postelj za bolnike z lažjo obliko bolezni. Role 2 je bila praktično izolirana od preostalega dela vojašnice, tako da so bili zagotovljeni vsi pogoji preprečevanje širjenja morebitnih okužb na preostale pripadnike v VEP-u (PSSV, 2020, str. 1-2).

Vojaška bolnišnica Role 2 je bila pred tem nameščena v Mariboru. Zakaj je bila Role 2 premeščena v Ljubljano? Odločitev se je zgodila na podlagi statističnih podatkov NIJZ o številu potrjenih primerov okužb, razdeljenih po regijah. V ljubljanski regiji je število potrjenih okužb prevladovalo nad preostalimi regijami, zato je bil premik Role 2 smiseln in vzpostavljen kot izolacijski center za potrebe okuženih državljanov. Kot rezultat ukrepov NIJZ in vladnih ukrepov ter zaradi prilagoditve civilnega zdravstvenega sistema Role $2 \mathrm{v}$ času razglašene epidemije ni bila uporabljena za potrebe državljanov.

Sledile so prekinitve notranjih letov in mednarodnega kopenskega prometa. Pišlar navaja, da je SV z lastnimi zmogljivostmi (Falcon, PC-6 in z evakuacijskimi vozili) varno pripeljala v domovino kar nekaj slovenskih državljanov. Na mejnih prehodih in letališčih je mobilna medicinska ekipa VZE izvajala zdravniško obravnavo (merjenje telesne temperature, odvzem brisa in seznanitev z ukrepi v primeru okuženosti ter izpolnjevanje vprašalnika) (2020, str. 6).

Z dobavo cepiva je bilo v prostorih Športne dvorane vojašnice Petra Petriča Kranj vzpostavljeno cepilno mesto, namenjeno cepljenju občanov mestne občine Kranj in drugim pripadnikom SV ter drugim varnostno-obrambnim organom (LOGBR, 2021, str. 1-2).

\subsection{Sodelovanje SV v mednarodnih operacijah in na misijah med epidemijo covida-19}

SV v mirovnih operacijah in na misijah deluje že od leta 1997. Takrat je bila to humanitarna operacija, v kateri so sodelovali pripadniki VZE, ki so skrbeli za zdravstveno oskrbo sil. Danes pripadniki SV delujejo na 12 različnih geografskih območjih, delovanja SV so usmerjena predvsem v Jugovzhodno Evropo, na Bližnji vzhod, v Srednjo Azijo in Severno Afriko (po Kremžar, 2014, str. 108).

V času slabšanja globalnih epidemioloških razmer je bila predvidena menjava številčno največjega kontingenta SV na območju delovanja na Kosovu. Glede na Odlok o odrejanju in izvajanju ukrepov, povezanih s preprečevanjem širjenja 
bolezni covid-19 in Odredbe o razglasitvi epidemije (Ur. 1. 29/20) ter novih smernic NIJZ in formalnih usmeritev Nata, smo pripravili usmeritve za pripadnike SV pred napotitvijo v tujino in po njihovi vrnitvi (MO, 2020, str. 1-2). Kot navaja Jurkovič v kroniki delovanja EUTM Mali je Nato nazadnje posredoval odločitev, ki jo je potrdil tudi državni vrh RS, da se za določen čas, dokler se epidemiološke razmere ne izboljšajo, ustavijo menjave kontingentov za vsa območja delovanja (2020, str. 13). Pripadnike SV v MOM, ki so bili zdravstveno ogroženi, domnevno okuženi ali so imeli opravičljive razloge za vrnitev v domovino, smo evakuirali ter zanje ustrezno poskrbeli. V času, ko je bila predpisana obvezna karantena pred odhodom v tujino in po njihovi vrnitvi v domovino (Ur. 1., 68/20, str. 2495), smo pripravili strokovno podprte usmeritve, ki so ustrezale zahtevam, potrebnim za vzpostavitev karantene v vojašnicah in vojaških objektih (MO, 2020). S temi akti smo seznanili pripadnike na vseh mirovnih misijah in v operacijah. V nadaljevanju bomo podrobneje opisali razmere na Kosovu, v Bosni in Hercegovini ter v Maliju.

\section{O delovanju Slovenske vojske na Kosovu}

Pripadniki slovenskega kontingenta Kfor 40 so zaradi izrednih razmer podaljšali svoje poslanstvo na Kosovu. Epidemiološka slika na Kosovu se je vse bolj slabšala, kar je posledično vplivalo tudi na širjenje obolenja med pripadniki v bazi Peć in Priština. Za slovenske pripadnike, za katere se je po oceni zdravnika VZE izkazalo, da spadajo v rizično skupino, je bilo poskrbljeno tako, da smo jih evakuirali v domovino. Evakuacija je bila izvedena s Turboletom L-410, v katerem se je notranjost plovila priredila tako, da je bila posadka zaščitena pred morebitno okuženimi pripadniki. Na podlagi ukaza poveljnika sil SV je na Kosovo odšla ekipa Veterinarske enote (VETE), namenjene za dezinfekcijo prostorov in vozil. Pišlar piše, da je v tem kritičnem času SV z lastnimi zmogljivostmi in sredstvi opravila dezinfekcijo prostorov in vozil slovenskega kontingenta ter tudi vozil tujih oboroženih sil. Tako je VETE v desetih dneh opravila dezinfekcijo 60 objektov in 42 vozil. Oborožene sile Avstrije in Italije so VETE SV posredovale zahvalo za tak odziv in solidarnost (2020, str. 6).

\section{Sodelovanje Slovenske vojske v Bosni in Hercegovini}

Pripadniki SV sodelujejo v okviru operacije Althea v Bosni in Hercegovini, katere namen je zagotavljanje vojaške navzočnosti ter prispevanje k vsesplošni stabilnosti. Na Balkanu je bila porast okužb precej višja v primerjavi s pojavom okužb v Sloveniji. Zaradi preprečevanja širjenja okužb in pravočasne izolacije obolelih pripadnikov se je zdravstvena ekipa VZE napotila na območje delovanja, kjer so odvzeli nekaj več kot 170 brisov pripadnikom SV in pripadnikom tujih oboroženih sil. Delež odvzetih brisov so analizirali v mobilnem biološkem laboratoriju SV. 


\section{Sodelovanje Slovenske vojske v EUTM Mali}

Leta 2013 je bil na misijo v Mali poslan prvi pripadnik SV. Gre za misijo EU, katere namen je usposabljanje oboroženih sil Malija (EU - Training Mission). ${ }^{4}$ Tokrat je na misiji sodelovalo devet pripadnikov SV. Februarja je Svetovna zdravstvena organizacija razglasila pandemijo zaradi bolezni covid-19. Marca so bili zaradi razglašene epidemije v Sloveniji sprejeti novi preventivni ukrepi za preprečevanje širjenja bolezni. Posledično je bilo za pripadnike EUTM Mali preklicano koriščenje misijskega dopusta, tako so pripadniki SV ostali na območju delovanja in nadaljevali svoje delo. Virus, ki se je razširil na vse celine, se je konec marca pojavil tudi v Maliju. Iz poročila, imenovanega Kronika delovanja EUTM Mali, je razvidno, kako Jurkovič opiše kronološki potek okužbe pripadnika s covid-19. S takojšnjim odzivom so se $\mathrm{v}$ domovini začele priprave na strateško medicinsko evakuacijo obolelega pripadnika iz Malija v Slovenijo. Slika 2 (str. 108) prikazuje strateško medicinsko evakuacijo, v kateri je zdravstvena ekipa VZE poleg okuženega pripadnika SV v Evropo evakuirala še enega pripadnika oboroženih sil Avstrije in dva pripadnika oboroženih sil Italije, ki so bili prav tako okuženi (2020, str. 13-14).

\section{Ukrepi za preprečevanje širjenja covida-19 v Slovenski vojski}

V Slovenski vojski je bilo v času razglašene epidemije sprejetih kar nekaj ukrepov za preprečevanje širjenja virusa. Poleg preventivnih ukrepov, ki jih je sprejela NIJZ, so v SV sprejeli še dodatne in selektivne ukrepe, ki jih bomo predstavili v nadaljevanju.

Vlada RS je 18. oktobra 2020 že drugič izdala Odlok o razglasitvi epidemije nalezljive bolezni covid-19 na območju celotne države (Ur. 1. 146/20). Že mesec pred tem je bilo zaznati večji porast števila okuženih prebivalcev, z razglasitvijo epidemije pa so se poostrili ukrepi za preprečevanje širjenja covida-19.

SV ni le sledila državnim ukrepom za zajezitev širjenja virusa, temveč so glede na aktualno epidemiološko situacijo bili izdani novi ukrepi. Grmadnik omenja ustanovitev strokovne svetovalne skupine za covid-19, katere namen je, da na podlagi empiričnih analiz zajezi prenos med pripadniki in predlaga dodatne in selektivne ukrepe poveljniku sil SV pri sprejemanju odločitev (2020, str. 9).

Oktobra je bilo zaznati povečano število okuženih pripadnikov, kar je za SV kot organizacijo, katere naloge in poslanstvo se bistveno razlikujejo od civilne sfere, predstavljalo nov izziv. Glavna naloga strokovne svetovalne skupine je bila in je še vedno dnevno spremljanje podatkov o okuženih pripadnikih in njihovih tesnih stikih ter s posebnim programom njihovo analiziranje. Rezultate analize proučijo in nadrejenim predlagajo morebitne dodatne ukrepe za zajezitev širjenja bolezni covid-19.

Slovenska vojska. Mednarodno sodelovanje Mali (EUTM), http://www.slovenskavojska.si/ mednarodno-sodelovanje/mednarodne-operacije-in-misije/mali/ 
Tako so se ustavila vsa nenujna usposabljanja, delo je bilo organizirano tako, da je bilo čim manj stikov, prednost je imelo delo na domu, sestanki so potekali prek avdio-video konferenc, $\mathrm{v}$ vojaških kuhinjah in jedilnicah so bile zagotovljene ustrezne razmere za vzdrževanje medosebne distance.

Čeprav so se spremljale epidemiološke razmere tako v Sloveniji kot v SV in so se sproti sprejemali dodatni preventivni ukrepi, je bila krivulja naraščanja okuženih pripadnikov sorazmerna krivulji naraščanja okuženih prebivalcev. Strokovna svetovalna skupina za covid-19 je ugotovila, da bodo potrebni dodatni organizacijski in strateški ukrepi. To je bil povod za takojšnjo vzpostavitev učinkovitega nadzora nad epidemiološkimi razmerami v SV. Prvi korak k vzpostavitvi nadzora je bilo jasno navodilo vsem pripadnikom SV, da morajo nemudoma poročati ob pojavu simptomov, značilnih za covid-19, ob potrjeni okužbi in tesnem stiku s pozitivno osebo doma ali na delovnem mestu.

Na strokovnem posvetu smo se odločili, da je treba vse simptomatske pripadnike SV takoj testirati, saj se tako omogoči zgodnje odkrivanje okužb. Prav tako je nujno neprekinjeno sledenje vsem visoko rizičnim stikom pozitivnih pripadnikov in jih takoj izolirati oziroma izločiti iz delovnega procesa. Vsi pripadniki, ki so poročali o visoko rizičnem stiku zunaj delovnega mesta, so bili takoj napoteni v karanteno. Poleg tega je poveljnik sil SV sprejel odločitev o uporabi hitrih antigenskih testov, s katerimi se pravočasno odkrijejo okuženi pripadniki, ki še ne kažejo znakov bolezni. $\mathrm{S}$ hitrimi antigenskimi testi se testirajo pripadniki pred odhodom na varovanje državne meje, pred skupinskim usposabljanjem ter pripadniki pred odhodom na misijo (MO, 2020, str. 2-5). S temi ukrepi se pravočasno izloči okuženi pripadnik in prepreči nadaljnje širjenje znotraj vrst SV.

Iz statističnih podatkov, pridobljenih iz sistema Pyramid, je razvidno uspešno preprečevanje širjenja okužb med pripadniki in uspešno obvladovanje epidemioloških razmer v SV, kar se vidi iz spodnjih grafov.

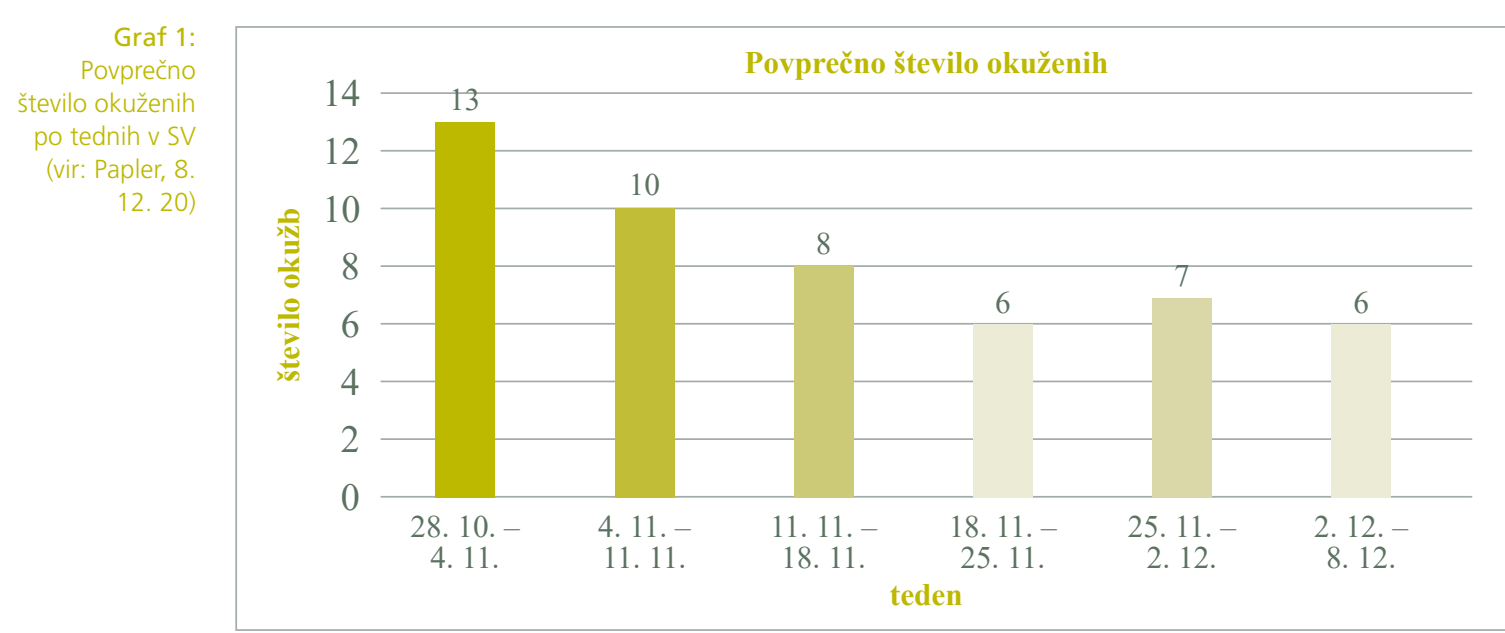


Z vsemi zgoraj opisanimi ukrepi se je v petih tednih zmanjšalo povprečno število okuženih pripadnikov na polovico, kar se vidi iz grafa številka 1.

Grafa št. 2 in 3 prikazujeta mesto prenosa okužbe. V 14 dneh se je delež prenosa okuženosti na delovnem mestu precej zmanjšal. Kljub temu je SV izvajala pomembne zmogljivosti in pomagala državi.

Graf 2:

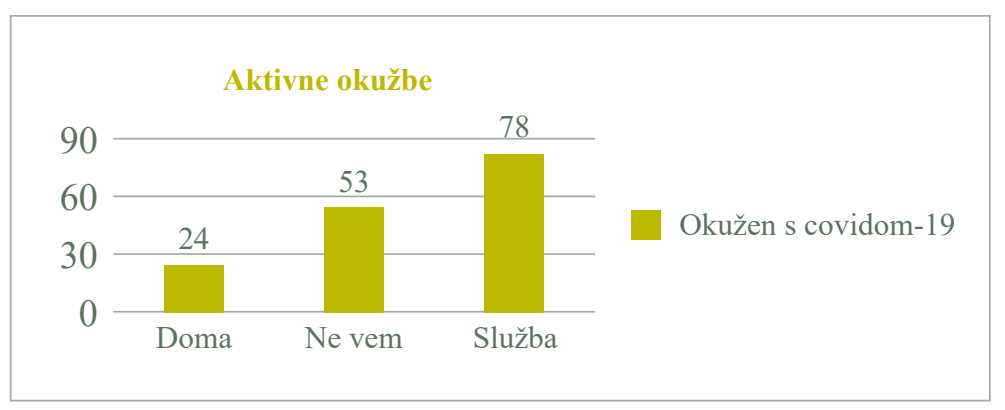

Graf 3:

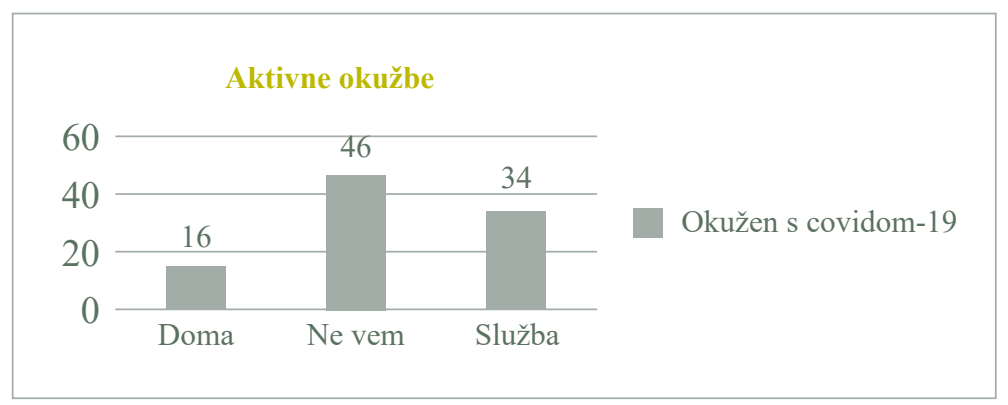

Sklep Kljub razglašeni epidemiji so enote SV preverjale eno od svojih bistvenih nalog, in sicer usposobljenost ter vzdrževanje stopnje pripravljenosti. V tem času so bile zelo pomembne usmeritve poveljnika sil SV, ki vključujejo predvsem ohranitev zdravja pripadnikov SV ter ohranitev zmogljivosti, in sicer tako bojne kot zmogljivosti zaščite in reševanja. Na podlagi poročila PSSV je SV posredovala podporo pri uresničevanju Zakona o varstvu pred naravnimi in drugimi nesrečami ter pomagala drugim državnim organom in vzdrževala operativnost v mednarodnih operacijah in na misijah (MO, 2020, str. 1-2).

Osnovno vprašanje je bilo, zakaj je bila epidemiološka slika drugega vala epidemije v SV tako slaba, kljub dodatnim, še ostrejšim ukrepom v primerjavi z nacionalnimi ukrepi. 
$\mathrm{Na}$ to lahko le delno odgovorimo. Upoštevati moramo, da kot pripadniki SV nismo izolirani od preostalega sveta in imamo zelo veliko stikov. K večjemu številu okuženih v drugem valu je poleg prej omenjenega prispeval tudi delež opravljenih testiranj, saj je bilo tako odkritih veliko okužb, ki so bile zaradi asimptomatike prikrite. Ozaveščenost pripadnikov SV glede preventivnih ukrepov je bila na visoki ravni, njihovo upoštevanje pa je bilo vsaj v začetku drugega vala epidemije nekoliko podcenjeno. Poleg tega se je z oblikovanjem strokovne svetovalne skupine za covid-19, ki je vsak dan spremljala ne le okužene, sume na okužbo, temveč tudi ugotavljala vse visoko rizične stike, ki so bili nemudoma izločeni iz delovnega procesa, učinkovito zmanjšalo število okuženih pripadnikov SV. Kot v svojem poročanju navede Papler, smo s sistemom kontrole nadzorovanja tesnih stikov zagotovili zgodnje odkrivanje okužb, kar je bistveno izboljšalo epidemiološko sliko v SV (2020, Poročilo COVID19). Dobre prakse so torej povečan nadzor in spremljanje visoko rizičnih stikov z okuženo osebo tako na delovnem mestu kot zunaj delovnega mesta. Eden izmed pomembnih dejavnikov zmanjšanja okužb je pravočasno ozaveščanje pripadnikov glede preprečevanja širjenja virusa ter upoštevanja vseh veljavnih ukrepov. Posameznik je tisti, ki prispeva h kolektivni zaščiti preprečevanja širjenja covida-19.

Danes se spoprijemamo z zdravstveno krizo, ki je ves svet pahnila v boj z virusom, ki mu še ni videti konca. Na vidiku je tretji val epidemije, ukrepi za preprečevanje širjenja virusa so znani, seveda pa je uspešnost preprečevanja širjenja virusa odvisna od posameznika, od tega, koliko upošteva ukrepe.

Pandemija predstavlja boj človeštva proti virusu, ki povzroča precej nepredvidljivo bolezen in ne pomeni le krize v zdravstvenem sistemu, temveč vodi v ekonomsko, gospodarsko, šolsko, pravzaprav v vsesplošno krizo. Če se vrnemo v preteklost in preletimo zgodovinsko pomembne dogodke, mejnike, ki so spremenili svet, je bilo stanje vsesplošnega pomanjkanja ter nezadovoljstva množic stanje krize ${ }^{5}$, ki je vodila v vojno.

Povzamemo lahko večkrat izrečene besede poveljnika sil SV, da je vojsko treba modro uporabiti, in sicer takrat, ko drugi instrumenti odpovejo. Predvsem pa je v času krize covida-19 še posebej pomembno ohranjanje zdravja pripadnikov SV.

Ne dvomimo, da si je SV s svojimi dejanji med epidemijo med prebivalci Slovenije pridobila ugled. Kot majhna država smo svoja dejanja pokazali v vsej svoji veličini in kot navaja Mikuž (2012), so majhne države na področjih obrambe in zagotavljanja svoje varnosti razvile različne postopke. Odločitve, ki jih sprejemajo o nacionalni varnosti, zelo pogosto temeljijo na predhodnih izkušnjah. »Zavedati se moramo, da majhnost države ne pomeni njene šibkosti in da majhne države svojo >moč

\footnotetext{
Škerbinc: "V takih obdobjih je to, obrambno gledano, življenje na robu. Nihče ne more predvideti, kdaj bo kakšen dogodek sprožil učinek domin. Ne moremo ostati ravnodušni do tega, kar se že leta dogaja okoli nas. Po drugi strani pa seveda moramo ohranjati optimizem. Moramo verjeti $v$ to, da se bomo obranili vseh groženj. Verjeti moramo tudi vase in v institucije varnostnega in obrambnega sistema. Tudi in predvsem v Slovensko vojsko«(Delo, 2020).
} 
uporabljajo drugače kot velike, saj jo izkazujejo kakovostno in ne količinsko« (Kremžar, 2014, str. 107).

Za konec naj posebej poudarimo, da imamo za seboj izkušnjo epidemije, iz katere se učimo, da sta solidarnost in skrb bistveni za kolektivni uspeh nad epidemijo nalezljive bolezni. V tem času smo razvili in uporabili kar nekaj oblik dela za nemoteno delovanje obrambnega sistema. Razvili smo sistem spremljanja in nadzora okužb med pripadniki SV in s tem posledično obvladovanja širjenja bolezni covid-19. Vse pozitivne izkušnje prvega in drugega vala epidemije lahko uporabimo pri prihodnjih nepredvidljivih boleznih, v upanju, da se nam nikoli več ne ponovijo. Kaj bo prineslo cepljenje proti covidu-19 v smislu učinkovitosti preprečevanja širjenja te nalezljive bolezni in kakšen učinek bo imelo na posameznika, pa ostaja zaenkrat še odprto vprašanje. Ob tem se lahko navežemo še na Gandhijev rek, ki pravi »Ni pametno biti preveč prepričan o modrosti nekoga drugega. Zdravo je biti opomnjen, da lahko najmočnejši oslabijo in se najpametnejši motijo.«

1. Brožič, L., 2020. Ilegalne migracije in vloga slovenskih oboroženih sil. Sodobni vojaški izzivi. Znanstveno-strokovna publikacija SV, (22/3), str. 84.

2. Centers for Disease Control and Prevention. Coronavirusu Disease 2019, Questions and Answers. https://www.cdc.gov/coronavirus/2019-ncov/

3. Edge, H. M., Carlucci, S., Lu, D., 2020. The role of Force Health Protection in the Canadian Armed Forces response' to the COVID-19. Can Commun Dis Rep.;46(9):279.

4. Frelih, T., Kraigher, A., Učakar, V., Čakš Jager, N., Kustec, T., Šubelj, M., Vrdelja, M., 2012. Preiskava izbruha. NIJZ.

5. Furlan, B., Rečnik, D., Vrabič, R., Maraš, V., Cerkovnik, J., Špur, B., Šonc, M., Tušak, M., Ivanuša, M., Gorjup, B., Kojadin Lasič, U., Unger, M., 2006. Vojaška doktrina. Ljubljana: Defensor.

6. Grmadnik, J., 2020. Drugi val, nov izziv. Slovenska vojska. 11/2020, str. 9.

7. Jurkovič, P., in Jurjec, U., 2020. Kronika SVNKON 14 EUTM Mali. (SVNKON MALI, št. 871-31/2029-53, z dne 1. 9. 2020), str. 13-17.

8. Kremžar K., T., 2014. Vojaško medicinska obveščevalna dejavnost z omejenimi viri na primeru majhnih držav. Sodobni vojaški izzivi. Znanstveno-strokovna publikacija SV, 16(4), str. 107-108.

9. Marot, C., 2020. Poročilo izvedbe Stratmedevac z dne 11. 4. 2020, str. 7.

10. Mikuž, I., 2012. Strategy Research Project International Fellow. Influence Small State Force Design. United States Army War College.

11. Ministrstvo za obrambo Republike Slovenije, 2020. Ukaz za vzpostavitev varne oblike dela in odsotnosti v času trajanja epidemije COVID-19. (MO, št. 100-98/2020-3, z dne 20. 3. 2020). Ljubljana: MORS.

12. Ministrstvo za obrambo Republike Slovenije, 2020. Preventivni ukrepi za preprečevanje širjenja Koronavirusa - COVID-19 na MO - dodatno obvestilo. (MO, št. 181-2/2020-27, $z$ dne 14. 3. 2020). Ljubljana: MORS.

13. Ministrstvo za obrambo Republike Slovenije, 2020. Ukaz za organizacijo in izvedbo serije vaj PRESKOK. (PSSV, št. 603-15/2020-38, z dne 8. 5. 2020). Ljubljana: MORS.

14. Ministrstvo za obrambo Republike Slovenije, 2020. Spremembe in dopolnitve 3. dopolnila obveznih usmeritev za obravnavo zaposlenih na MORS pred napotitvijo v tujino in po njihovem povratku iz tujine v RS-COVID-19.(MO, št. 160-1/2020-578, z dne 29. 7. 2020). Ljubljana: MORS. 
15. Ministrstvo za obrambo Republike Slovenije, 2020. Načrt uvedbe izvajanja karantene ali izolacije za pripadnike SV v vojaškem objektu Ajševica. (1. BR, št. 160-12/2020-470, z dne 27. 5. 2020). Ljubljana: MORS.

16. Ministrstvo za obrambo Republike Slovenije, 2020. Postopkovnik uporabe PCR in hitrih antigenskih testov za SARS-CoV-2. (MO, št. 160-12/2020-843, z dne 27. 11. 2020). Ljubljana: MORS.

17. Ministrstvo za obrambo Republike Slovenije, 2021. Ukaz za sodelovanje LOGBR pri organizaciji in izvedbi množičnega cepljenja Občanov občine Kranj proti COVID-19. (LOGBR, št. 8012-2/2021-161, z dne 16. 3. 2021). Ljubljana: MORS.

18. Nacionalni inštitut za javno zdravje. Priporočila za preprečevanje okužbe z virusom SARS-CoV-2, 2020, https://www.nijz.si/sl/priporocila-za-preprecevanje-okuzbe-z-virusomsars-cov-2

19. Odlok o razglasitvi epidemije nalezljive bolezni COVID-19 na območju Republike Slovenije, 2020. Uradni list RS, 166/20.

20. Odlok o odrejanju in izvajanju ukrepov, povezanih s preprečevanjem širjenja COVID-19, na mejnih prehodih na zunanji meji in na kontrolnih točkah na notranjih mejah RS, 2020. Uradni list 68/20.

21. Odlok o razglasitvi epidemije nalezljive bolezni COVID-19 na območju RS, 2020. Uradni list, $146 / 20$.

22. Odredba o razglasitvi epidemije nalezljive bolezni SARS-CoV-2 (COVID-19) na območju Republike Slovenije, 2020. Uradni list RS, 29/20.

23. Papler, L., 2020. Poročilo COVID-19, Power Point predstavitev, 8. 12. 2020.

24. Pasquier, P., et al. How do we fight COVID-19? Military medical action in the war against the COVID-19 pandemic in France. BMJ Mil Health Month 2020, str. 1-2.

25. Pišlar, M., 2020. Poveljnikova dolžnost je zagotoviti najboljše razmere za usposabljanje. Slovenska vojska. 6/2020, str. 5-6.

26. Plibeř̌ek, A., 2012. Nevojaške naloge oboroženih sil. (Diplomsko delo). Maribor. Fakulteta za varnostne vede.

27. Poveljstvo sil Slovenske vojske, 2020. Posredovanje INFO za URSZR o izvedenih nalogah po COVID. (PSSV, št. 842-1/2020-115, z dne 4. 6. 2020). Ljubljana: MORS.

28. Poveljstvo sil Slovenske vojske, 2020. Posredovanje INFO za URSZR o izvedenih nalogah po COVID. (PSSV, št. 842-1/2020-115, z dne 4. 6. 2020). Ljubljana: MORS.

29. Poveljstvo sil Slovenske vojske, 2020. Ukaz za delovanje sil SV v času poslabšanja epidemiološke situacije COVID-19 ter delovanje strokovne svetovalne skupine COVID-19 za pridobivanje epidemioloških podatkov (PSSV, št. 842-1/2020-155, z dne 18. 9. 2020) z vsemi dopolnili. Ljubljana: MORS.

30. Tagarev, T. 2020. Balancing Defense and Civil Support Tasks: The Impact of Covid-19 on the Bolgarian Military's Roles. The Quarterly Journal. 2/20, str. 61-73.

31. Resolucija o splošnem in dolgoročnem programu opremljanja in razvoja Slovenske vojske do leta 2025 (ReSDPRO), 2010. Uradni list RS, 99/10.

32. Slovenska vojska. Mednarodno sodelovanje Mali (EUTM Mali), http://www. slovenskavojska.si/mednarodno-sodelovanje/mednarodne-operacije-in-misije/mali/

33. Škerbinc, M., 2020. Vojska je kraljev zadnji argument in ne kraljeva dekla. Delo, https:// www.delo.si/novice/slovenija/vojska-je-kraljev-zadnji-argument-in-ne-kraljeva-dekla/, 7. 1. 2020

34. Vojaško zdravstvena enota, 2020. Postopki merjenja telesne temperature na kontrolnih točkah vstopa na območje SV (VZE, št. 160-12/2020-231, z dne 24. 3. 2020).

35. Zakon o obrambi, 2004. Uradni list RS, 103/04. 


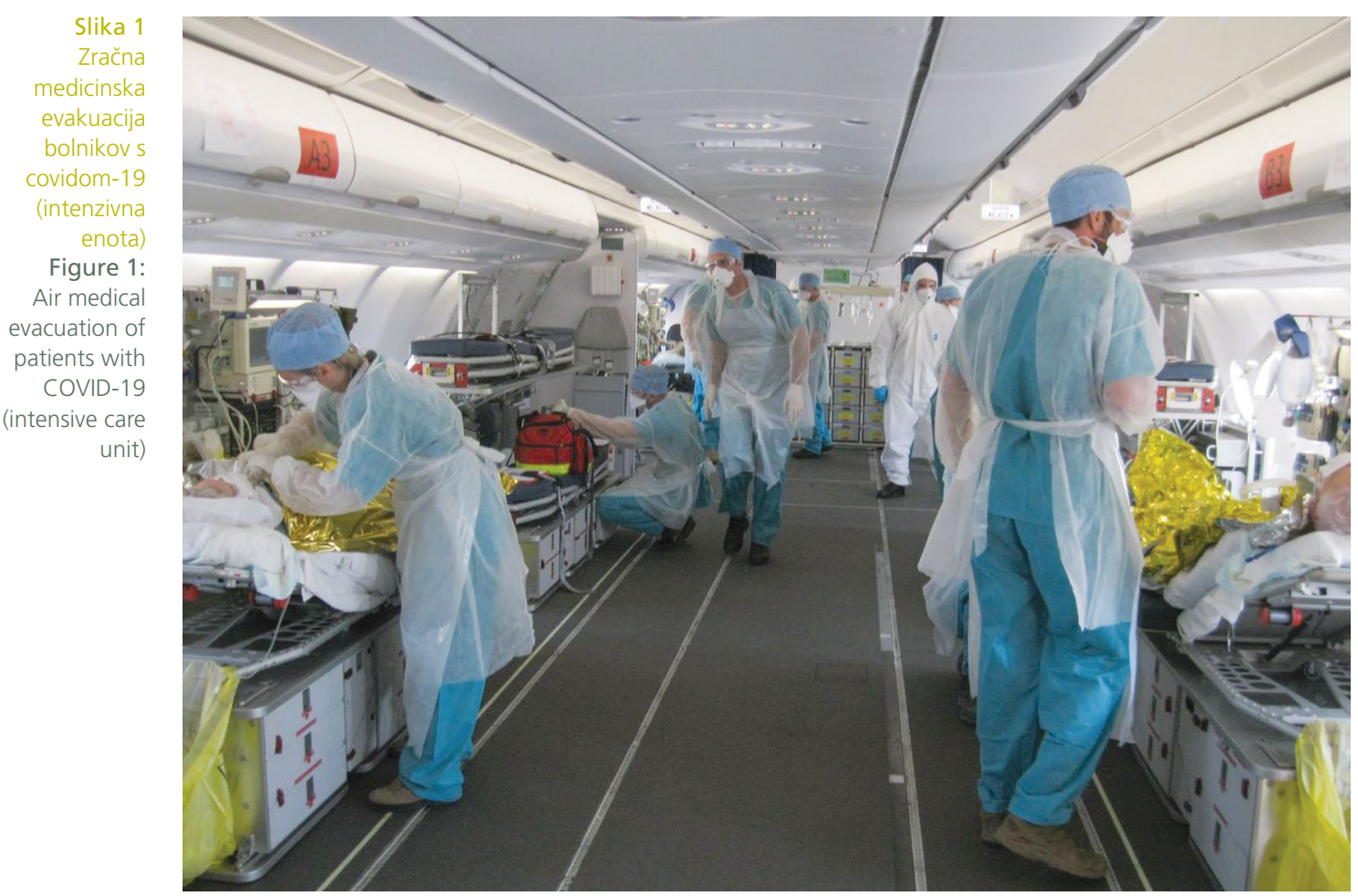

Slika 2

Strateška

medicinska

evakuacija (vir:

Marot, 2020,

Figure 2:

Strategic

medical

evacuation

(Source: Marot,

2020, p. 7)

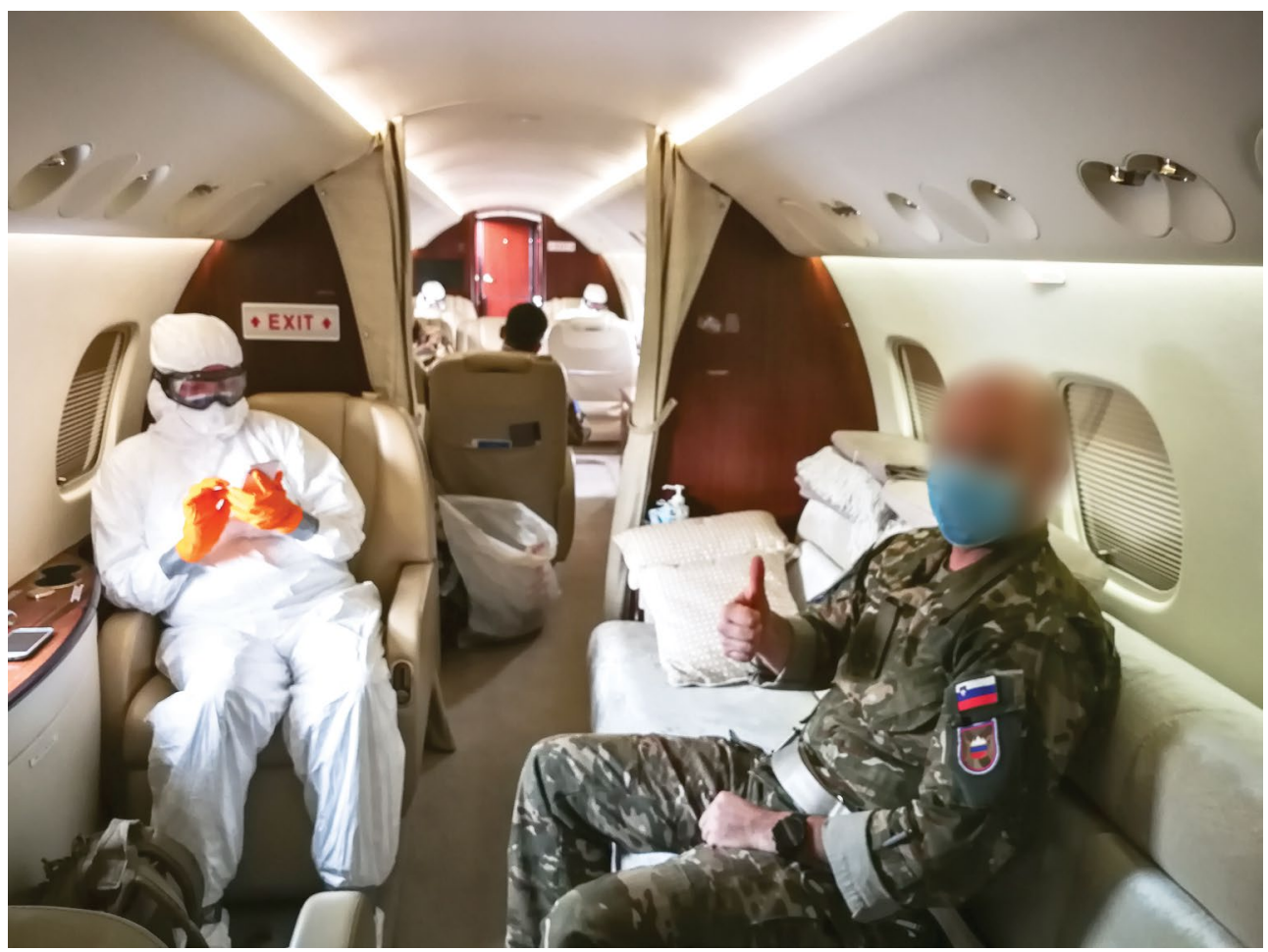

